\title{
Retracted: Review of Hypofractionated Radiotherapy for Prostate Cancer
}

\author{
ISRN Oncology \\ Received 6 December 2012; Accepted 6 December 2012 \\ Copyright (C 2012 ISRN Oncology. This is an open access article distributed under the Creative Commons Attribution License, \\ which permits unrestricted use, distribution, and reproduction in any medium, provided the original work is properly cited.
}

This article has been retracted as it is found to contain a substantial amount of material from the paper "Hypofractionation for Prostate Cancer: A Critical Review," Edward F. Miles, W. Robert Lee, Seminars in Radiation Oncology January 2008 (Vol. 18, Issue 1, Pages 41-47, DOI: 10.1016/ j.semradonc.2007.09.006) [1].

\section{References}

[1] D. Spyropoulou and D. Kardamakis, "Review of hypofractionated radiotherapy for prostate cancer," ISRN Oncology, vol. 2012, Article ID 410892, 5 pages, 2012. 